Volume 6, Issue 2, 135 - 144.

ISSN: $2165-8714$

http://www.eu-jer.com/

\title{
Scrutinizing the Factors Affecting Fluency of English among Arab Learners
}

\author{
Fawzi Al Ghazali * \\ ALHOSN University, UAE
}

Received: March 3, $2017 \cdot$ Accepted: March 31, 2017

\begin{abstract}
This research study investigates the cognitive, psychological and personal factors affecting the accuracy and fluency of English language usage among Arab learners. Early research led by Chomsky (1965) and Krashen (1981) suggested that an individual's Language Acquisition Device once triggered at the appropriate time and supported with adequate Comprehensible In put can lead to automatic development of an L2. Relevant research suggests that children are born with the instinct or innate facility for language acquisition provided they have no physical or mental impairment (Al Ghazali, 2006). However, past research (Engin and Seven, 2014; Hanani, 2009; Gupta, 2008; Latu, 1994) has led to the identification of additional factors that go beyond the cognitive domain. These factors were examined individually and against a background of teaching methods, phonetics application, and classroom conditions. In this research, a mixed research study was designed in which a survey and interviews were conducted with a number of university students. With minimal effect from the researcher, the data were collected to examine the influence of these factors on learners' proficiency of English language and application. The findings reveal that Arab learners' ability to learn English is dependent on psychological motivation, physical needs to apply it, and personal reasoning.
\end{abstract}

Keywords: Proficiency, language acquisition, psychological factors, linguistic input, language education.

To cite this article: Al Ghazali, F. (2017). Scrutinizing the factors affecting fluency of English among Arab learners. European Journal of Educational Research, 6(2), 135-144. doi: 10.12973/eu-jer.6.2.135

\section{Introduction}

Learning English as a foreign language in the Gulf region demands pedagogical expertise from various points: psychological, cognitive, economic, and sociocultural. The performance of Arab students learning English as a foreign language becomes challenging when the scope of communicating in English is limited outside the classroom. Also, in the classroom, English teachers may find it difficult to encourage students displaying better language performance in and outside of the classroom to support other students who may not be as confident or are hesitant. In this context, the area of learning English as a foreign language has been a subject of frequent research by scholars, with each researcher trying to bridge the gap. While some scholars have focused on the role of teachers in the teaching and learning process (Ansari, 2012; Salameh, 2012; Bekdas, 2015); others have looked into the importance of curriculum, qualification of teachers, and administration (Qashoa, 2006; Alhaisoni, 2012; Zainol Abidin, Pour-Mohammadi and Alzwari, 2012). However, the fluency of Arab learners in English and the factors that affect their performance in application and communication is rather under-researched. It is still relatively unknown if the Arab learners' failure to gain a nativelike fluency of English is attributed to the structural dissimilarity (in terms of phonemes and morphemes) of the first language (Arabic). In addition, few studies have investigated the role of Arab culture in facilitating or debilitating the attainment of native-like proficiency of English. These points represent the scope of this research.

\section{Literature Review}

There are various studies conducted in the area of teaching English as a foreign language; however, in perspective of the present research, there are few studies available. As stated by Chomsky (1965), every person has a Language Acquisition Device (LAD) - a neurotic understanding leading to acquisition of a language. Applying the LAD principle, a person can successfully acquire a second language by following a similar process as applied for the first language acquisition. While it is important to note that the acquisition of the first language may not have negative experiences and have followed an automatic process, acquiring the second language may not be the same. The following sections present a detailed analysis of some of the key themes identified in the past to affect the fluency of English in Arab

\footnotetext{
* Correspondence:

Fawzi Al Ghazali, ALHOSN University, P.O. Box 38772, Abu Dhabi, UAE

Email: f.alghazali@alhosnu.ae
} 
learners (Alrabai, 2016; Charise, 2007; Othman \& Shuqair, 2013) as well as models listed by key linguists. The review will be applied towards the research framework and research design. The main themes are as follows:

Table 1: Main Themes in the Literature

\begin{tabular}{|c|c|c|}
\hline Factors & Main Theme & Sources \\
\hline Class Size & Smaller class size is required for effective results. & $\begin{array}{l}\text { (Nguyen, Warren and Fehrin, 2014; } \\
\text { Derderian-Aghajanian, 2012; Engin and } \\
\text { Seven, 2014) }\end{array}$ \\
\hline Assessment Control & $\begin{array}{l}\text { Better assessment methods can ensure better } \\
\text { standards. }\end{array}$ & $\begin{array}{l}\text { (Nguyen, Warren and Fehrin, 2014; } \\
\text { Engin and Seven, 2014) }\end{array}$ \\
\hline $\begin{array}{l}\text { Available resources } \\
\text { for teachers }\end{array}$ & $\begin{array}{l}\text { Teachers need support from institutions to invest } \\
\text { more in lessons. The resources are not streamlined } \\
\text { at different levels. }\end{array}$ & $\begin{array}{l}\text { (Nguyen, Warren and Fehrin, 2014; } \\
\text { Alrabai, 2016; Engin and Seven, 2014) }\end{array}$ \\
\hline $\begin{array}{l}\text { Native speaker } \\
\text { teachers of English }\end{array}$ & $\begin{array}{l}\text { The hiring of native English teachers in secondary } \\
\text { schools helps. }\end{array}$ & $\begin{array}{l}\text { (Engin and Seven, 2014; Hanani, 2009; } \\
\text { Gupta, 2008) }\end{array}$ \\
\hline $\begin{array}{l}\text { Dominance of } \\
\text { native language }\end{array}$ & The dominance of Arabic hinders EFL development. & $\begin{array}{l}\text { (Alrabai, 2016; } \quad \text { Salameh, 2012; } \\
\text { Rabab'ah, 2014) }\end{array}$ \\
\hline Teaching methods & The use of static methods restricts EFL teaching. & $\begin{array}{l}\text { (Alrabai, 2016; Saffarini and Ismail, } \\
\text { 2008) }\end{array}$ \\
\hline Motivation & $\begin{array}{l}\text { Lack of motivation is a key factor in decreasing the } \\
\text { efficiency of teaching EFL. }\end{array}$ & $\begin{array}{l}\text { (Alrabai, 2016; Othman and Shuqair, } \\
\text { 2013; Salameh, 2012) }\end{array}$ \\
\hline
\end{tabular}

From a cognitive perspective, the monitor theory developed by Krashen (1981) extends the LAD principle by introducing factors that affect second language acquisition: input, natural order, affective filter and acquisition versus learning. Today, these domains form the basis for the teaching process or strategies applied in formal and informal second language acquisition settings. Krashen highlighted the importance of different learning inputs to activate the LAD in learners, including attitude and motivation to learn the second language. These factors were also highlighted within the conscious reinforcement model by Carrol (1981) and strategy model by Bialystok (1978).

The presence or lack of motivation is a critical factor in developing fluency and accuracy in any language. According to Othman and Shuqair (2013), it has been difficult to teach English as a foreign language in the Gulf States because the motivation levels required to drive language learning are missing. The authors argue that the learning of a language requires the presence of both intrinsic and extrinsic motivation for developing proficiency. The accuracy levels of Arab learners therefore, are dependent on their motivation levels, especially during their high school studies. By defining fluency of English as being able to communicate using both receptive and productive skills, it is argued that learners' intrinsic motivation, initiation, and proactivity to explore different avenues for practising the language are influential elements in mastering a foreign language (Al Ghazali, 2006). In addition, motivation of Arab learners is affected by external factors, such as the lack of the availability of native-speaker teachers to deliver lessons in accurate and reliable English (Alrabai, 2016). Qashoa (2016) further raises concern that motivation for learning English is reduced when students face problems in terms of understanding the grammar, structure, vocabulary and spelling of the language during the study period. However, Drbseh (2015) raises the point that motivation is the key element in learning English irrespective of the studies chosen. To elaborate more, learners' motivation decreases in situations when they feel reluctant to contribute either because they are not aware why to learn English this way or because they are not aware how to practise it in situations outside the borders of formal instruction settings (Al Ghazali, 2006). Other elements that affect learners' motivation are related to ineffective teaching method, segmentalization of language aspects, and presenting language forms in less authentic situations like those in which they are actually used.

Another factor affecting the motivation of Arab learners to attain fluency in English is their dependency on Arabic language not only in daily communication but in thinking patterns as well (Alrabai, 2016). Learners fail to understand the importance of learning English which further restricts their motivation to learn the language. Alrabai also found that most Arab teachers in this region tend to resort to using the Arabic language when explaining difficult topics to their students. Applying local language during the explanation may be a good strategy; however, it increases Arabic language dependency. Dmour (2015) observed that the use of Arabic in Jordanian classroom settings often undermines the importance of English. Such a strategy can lead to two results: the students can gain higher proficiency in English due to better understanding of the new language as a result of Arabic explanations, or they may not be able to discard the lingering effect of using the local language. Hamadallah (1999) argued that it is essential to rely on Arabic when trying to teach English as a second language. This viewpoint can hardly be supported by the majority of language educators and psycholinguists who believe that teaching English using English in authentic contextual situations permits the attainment of robust, permanent knowledge. It also trains them to think and communicate in English rather than formulating ideas in their native language and then transforming them into English. 
The influence of First language (F1) on Second Language (L2) is extensively studied by linguists and educators. The use of prepositions, for example, represents a problem for many Arab learners who try to compare English prepositions with those used in Arabic. An Arab learner may say "knock on the door" and finds it similar to what he/she says in Arabic, while a native speaker of English finds that "knock at the door" is a more collocating phrase. Similarly, the use of phrasal verbs such as "set in, set off, set out" constitutes an exceptional challenge for many Arab learners. Clark (1993: 10), moreover, believes that "conceptual organisation and its component concepts are not the same as the meanings for the lexical items of a language". To signify the discrepancies between L1 and L2, he points out that English speakers typically use "put on" as one verb in talking about dressing. The Japanese, for example, use a much more elaborate lexicon for talking about dressing. They use one verb for garments on the upper body, another verb for the lower body, a third verb for arms and legs, and a forth verb for accessories like watches, necklaces, earrings, etc. Hence, fluency of English depends to a great extent on the ability to reduce influence of L1 and possibility to identify the different lexicons of each language.

From a cultural perspective, Hopkyns (2014) points out that English can act as a double edged sword and decrease the dominance of the native culture among younger generations. Similarly, Charise (2007) asserts that English can sometimes be associated with the entry of Western elements into the Arab region particularly among elder generations; so that advocating for teaching English can often be considered as culturally moving away from the Islamic practices of the Arab countries. English can also be associated with the implicit forms of Colonialism, and this is liable to restrict the outlook of the elder generation of Arab people to perceive the importance of English and how it can affect their children (Charise, 2007). It can be attributed to the point that cultural effects in the form that they occur may be due to stereotyping of the Arab culture and the belief that the advancement of English may hinder their cultural identity. While these perceptions could have underlying principles driven by the level of understanding of the authentic culture, this attitude is not identical in all Gulf countries, even though they share a similar culture. The situation of interpreting instructions of Islam in the Kingdom of Saudi Arabia (KSA), for instance, is not twin to that in the Emirates currently viewed as the heaven of tourism and entertainment for many nationalities worldwide. Hence, the Arab culture per se is not to blame, but rather how people in each country interpret their local culture and the connection they make between it and religious principles are to be investigated instead.

Among the socioeconomic factors that affects Arab learners' fluency of English language (Salameh, 2012) is parental influence that may impact their interest in learning a foreign language. It is found that the interest in and performance of English by students is directly related to the family's socioeconomic factors. One research found that the age at which learners begin learning English is an important intrinsic factor affecting fluency of Arab learners. Early starters can develop proficiency much earlier, while late starters may never find themselves comfortable with English as the primary language for learning and communicating with the world (Gawi, 2012). This relates closely to the LAD principle of Chomsky on how LAD can influence a learner's proficiency in acquisition of a new language. Rabab'ah (2014) contends that Arab learners may face different types of social factors such as the lack of the natural environment in which people can interact with each other in English. This represents additional external factor that impacts learners' fluency in English.

From an affective perspective, poor learning attitude is a noted problem identified by many researchers that affects the SLA in the Arab region (Bekdas, 2015; Eshghinejad and Gritter, 2016). Thus the learning outcome is found to be directly related to the learner's attitude. It is found that Arabs choose to speak in English only if necessary in their respective personal and professional settings, resulting in low English proficiency levels throughout the Middle East (Eshghinejad and Gritter, 2016). The study by Behbahani (2016) also highlights that most learners apply a limited vocabulary which in turn limits their proficiency level to speak English language (Behbahani, 2016). One way to interpret these findings is to conclude that Arabs in general have not yet embraced the concept of English as a global language they will need to further develop their professional and financial life.

Table 2. Factors identified to affect fluency of Arab Learners in English Language

\begin{tabular}{cll}
\hline Factor & \multicolumn{1}{c}{ Focus } & \multicolumn{1}{c}{ Sources } \\
\hline Culture & $\begin{array}{l}\text { English is considered as culturally separate from the Arabs. It is a } \\
\text { foreign product that may decrease the Arab-ness of an individual }\end{array}$ & $\begin{array}{l}\text { (Charise, 2007; Hopkyns, 2014; } \\
\text { Derderian-Aghajanian, and Cong, }\end{array}$ \\
$\begin{array}{l}\text { according to popular belief. } \\
\text { Motivation }\end{array}$ & $\begin{array}{l}\text { The presence of motivation greatly helps in developing better } \\
\text { proficiency in English. Lack of motivation due to any reason is the } \\
\text { primary cause of poor English. }\end{array}$ & $\begin{array}{l}\text { Alrabai, 2016; Qashoa, 2006; } \\
\text { Drbseh, 2015) }\end{array}$ \\
\hline
\end{tabular}


Table 2: Continued

\begin{tabular}{|c|c|c|}
\hline Factor & Focus & Sources \\
\hline $\begin{array}{l}\text { Reliance on } \\
\text { Arabic }\end{array}$ & $\begin{array}{l}\text { Arab teachers often struggle to teach EFL. Many students rely } \\
\text { on Arabic in social life, therefore are not capable of developing } \\
\text { their English. }\end{array}$ & $\begin{array}{l}\text { (Alrabai, 2015; Dmour, 2015; } \\
\text { Hamdallah, 1999) }\end{array}$ \\
\hline $\begin{array}{l}\text { Socioeconomic } \\
\text { Factors }\end{array}$ & $\begin{array}{l}\text { Socioeconomic factors such as exposure to English in early age } \\
\text { determine English proficiency levels. }\end{array}$ & $\begin{array}{l}\text { (Salameh, 2012; Rabab'ah, 2014; } \\
\text { Gawi, 2012) }\end{array}$ \\
\hline $\begin{array}{l}\text { Poor Learning } \\
\text { Attitude }\end{array}$ & $\begin{array}{l}\text { The learning attitudes in the GCC are relatively low, because } \\
\text { students do not believe that they will need English during } \\
\text { everyday activities. }\end{array}$ & $\begin{array}{l}\text { (Behbahani, 2016; Bekdas, } \\
\text { 2015; Eshghinejad and Gritter, } \\
\text { 2016) }\end{array}$ \\
\hline
\end{tabular}

\section{Research Scope}

This research evaluated the degree to which the psychological, cognitive, and personal factors may influence the proficiency of Arab learners of English. The aim was to examine the influence of the above factors in real-time application of English language. Also, an attempt was made to identify how the application of English language differed in terms of proficiency levels amongst the Arab learners despite being exposed to the same linguistic input. More specifically, two research questions guide the development of this research paper namely:

- Which factors influence the accuracy and fluency levels of Arab learners?

- Why do the Arab learners have different levels of proficiency in English despite being exposed to the same linguistic input?

\section{Research Methodology}

Different methodologies have been developed to evaluate the acquisition of a foreign language such as English and to examine the fluency of Arab learners in learning English. In a study on EFL students in Saudi Arabia, Alrabai (2016) used a quantitative methodology to discuss the inability of the Saudi students to speak English language fluently. A recent research by Behbahani (2016) on EFL at the Modern Language Division of Eastern Mediterranean University in North Cyprus applied a similar method for proficiency analysis with a sample of 76 students. He utilized two tools: a proficiency test and a questionnaire with a 5-point Likert scale. A review of methods developed by past researchers in the area of English language acquisition is shared in the table 3.

Table 3: An evaluation of research methods applied in past research on EFL

\begin{tabular}{|c|c|c|}
\hline Author & Method Applied & Study Details \\
\hline Brown, D. J. (2014) & Mixed Methods Research for TESOL & $\begin{array}{l}\text { A detailed explanation on how mixed methods of } \\
\text { research can be applied in TESOL }\end{array}$ \\
\hline Bekdas (2015) & $\begin{array}{l}\text { Segmentation Methodology with } \\
\text { convenience sampling }\end{array}$ & $\begin{array}{l}\text { A research in Ankara, Turkey with a sample of } 645 \\
\text { students to identify the factor affecting English } \\
\text { language learning }\end{array}$ \\
\hline Dmour (2015) & Mixed research method & $\begin{array}{l}\text { Evaluated the effect of using Arabic for EFL learning at } \\
\text { elementary level in Jordan }\end{array}$ \\
\hline $\begin{array}{l}\text { Engin and Sven } \\
(2014)\end{array}$ & $\begin{array}{l}\text { Mixed research method with a } \\
\text { survey questionnaire } \\
\text { performance test }\end{array}$ & $\begin{array}{l}\text { Focused on evaluation of L1 and L2 teaching methods. } \\
\text { Targeted a sample of } 374 \text { Turkish teachers and } 178 \\
\text { students in Saudi Arabia }\end{array}$ \\
\hline $\begin{array}{l}\text { Nguyen, Warren and } \\
\text { Fehring (2014) }\end{array}$ & $\begin{array}{l}\text { Qualitative approach with deductive } \\
\text { reasoning }\end{array}$ & $\begin{array}{l}\text { Reviewed the different factors that affect EFL education } \\
\text { at the university level }\end{array}$ \\
\hline $\begin{array}{l}\text { Othman and Shuqair } \\
\text { (2013) }\end{array}$ & Secondary research (qualitative) & $\begin{array}{l}\text { Evaluated the impact of motivation of English } \\
\text { proficiency in the Gulf }\end{array}$ \\
\hline $\begin{array}{l}\text { Derderian- } \\
\text { Aghajanian and Cong } \\
\text { (2012) }\end{array}$ & $\begin{array}{l}\text { Qualitative approach with a sample } \\
\text { of } 4 \text { schools (elementary level) }\end{array}$ & $\begin{array}{l}\text { A research on the influence of regional culture on EFL } \\
\text { students and EFL education from China and Middle East }\end{array}$ \\
\hline
\end{tabular}

The best social science researches employ both qualitative and quantitative analyses (Rubin \& Babbie, 2009). Therefore, a mixed research design was selected for this research. Quantitative analysis allows the use of setting up a 
null hypothesis and then using research questions to either prove or disprove the hypothetical question (Watzlawik \& Born, 2007). The quantitative analysis was found to be most suitable, given the selection of multiple informants and the limited mobility of the researcher in the region. Supportively, a qualitative analysis using a focus group allows for observation based analysis. The selection of a focus group will allow the researcher to understand how the identified variables are affecting the students in real-time application of English language. This research is based on testing variables such as culture, reliance on Arabic language and socioeconomic problems. In support of the qualitative method, two population groups were developed: the first group comprised 330 university students from different institutes in the Gulf region, whereas the second group comprised 15 students selected for the focus group. For group 1, a semi-structured quantitative analysis method was applied.

\section{Results}

The data for the quantitative analysis were collected from a sample of 330 students: 130 students from the business studies, 50 students from the education department, and 150 students from the engineering department. A detailed list of the questions included in this research is shared in Appendix A.

\section{Demographic Profile}

A total of 330 students participated in the survey with 180 males and 150 females. The highest frequency of respondents was from the age group 19, 20 and 21 years. The minimum age of the respondents was 18 years with the oldest being 44. In total, respondents were identified from 14 different nationalities primarily from the Middle East; while a majority of the respondents were from the United Arab Emirates. The descriptive statistics for the demographic factors are shared in table 4 . The data show that mothers are typically more educated (with mean value closer to Masters for mothers and Bachelors for fathers). This supports the changing trend in the Arab countries regarding the increasing number of women going to the universities (Connerley \& $\mathrm{Wu}, 2015)$. There is parity between the educational levels in the parents of engineering students.

Table 4: Descriptive Statistics

\begin{tabular}{lccccc}
\hline & Age & Gender & Nationality & $\begin{array}{c}\text { Parent's } \\
\text { Education } \\
\text { Level Mother }\end{array}$ & $\begin{array}{c}\text { Parent's Education Level } \\
\text { Father }\end{array}$ \\
\hline Mean & 24.27 & 1.45 & 5.61 & 3.00 & 2.70 \\
Standard Error & 1.31 & 0.09 & 0.68 & 0.33 & 0.28 \\
Median & 21 & 1 & 5 & 2 & 2 \\
Mode & 19 & 1 & 5 & 2 & 2 \\
Standard Deviation & 7.55 & 0.51 & 3.91 & 1.92 & 1.59 \\
Sample Variance & 56.95 & 0.26 & 15.31 & 3.69 & 2.53 \\
Kurtosis & 1.75 & -2.09 & -0.20 & -1.35 & -0.72 \\
Skewness & 1.69 & 0.19 & 0.77 & 0.59 & 0.68 \\
Range & 26 & 1 & 13 & 5 & 5 \\
Minimum & 18 & 1 & 1 & 1 & 6 \\
Maximum & 44 & 2 & 14 & 6 & 89 \\
Sum & 801 & 48 & 185 & 99 & 330 \\
Count & 330 & 330 & 330 & 330 & \\
\hline
\end{tabular}

\section{Overview of the Responses}

The majority (50\%) of the quantitative respondents confirm using English language which can be attributed to the point that they started learning English language at a very young age (0-6). The other half started to learn English language in primary school while 3.3\% of the students indicated starting to study English in lower secondary. About $67 \%$ of the students have taken English language as a subject in their current studies while $3.3 \%$ of them have decided not to do so. All students use Arabic while at home, and the majority of them took IELTS with only a minority of students taking both TOEFL and IELTS.

The business students were comfortable with all aspects of English language. Except 7.69\% of them, they expressed their confidence in their capability to speak, listen, write and read English; with students sharing the support of their teacher. The education students were not comfortable with English language with the exception of $20 \%$ of them, in contrast to the engineering and business students. They indicated that they started studying English in secondary school. $60 \%$ of them have taken English as a subject in their current studies while the rest do not. Arabic is the language 
that is used at home, with family, and friends. There were only $20 \%$ of the education students who took the IELTS examination while the rest took neither TOEFL nor IELTS. They also were not confident in using English language and made errors, and did not have the appropriate vocabulary. Unlike students in the education department, the group of engineering students were keen to include English language in their current courses and relied on Arabic to converse with their family at home, while $20 \%$ of them used both languages. Almost all students in this group enrolled for IELTS or TOEFL.

Overall, $72 \%$ of the students strongly agreed that learning English is important for them to communicate with high proficiency level. Around $67 \%$ of the students agree with the perception that people who can speak fluent English are considered as more prestigious in the Arab world. Over 45\% of the students also strongly agree that they believe that their fellow students speak better English than themselves; $23 \%$ of the students believed they were better than others, and $23 \%$ remained neutral. $40 \%$ of the students expressed that they don't feel nervous while speaking English language; $14.5 \%$ of them felt nervous while speaking English in class and the rest remained neutral. 31.5\% of the students stated that they are only learning English because it is a requirement. The other $48.5 \%$ of them sincerely wanted to learn English. Out of the 330 students, $66 \%$ agreed that intellectual students have ease in learning languages while only $11.5 \%$ of them disagreed. Two thirds of the students agreed that their teacher should encourage them to speak English if they want to learn it. There were $8.5 \%$ of them who disagreed. Statistically $80 \%$ of the students agreed that their English language skills would improve if they were able to study it more. There were only $9.9 \%$ of the students who disagreed and rest chose to remain neutral.

\section{Analysis of the Focus Group}

The 330 students also acted as the targeted population for the focus group; however, only 15 chose to participate in the discussion. The researcher observed their behaviour and noted down the important details according to the questions developed for the focus group in Appendix A. It was observed that $80 \%$ of the students participating in the focus groups had no problem speaking English language with confidence while $20 \%$ of them displayed reluctance to speak. In terms of vocabulary usage, only $33 \%$ of the students were able to apply appropriate vocabulary to express themselves during the discussion, while the others hesitated while framing their sentences or tried to use Arabic words in between. This observation has been a subject of discussion in studies describing how vocabulary and language structure are among the top hindrances for students learning and using English in an accurate manner (Alrabai, 2016; Ansari, 2012; Gupta, 2008).

During the focus group discussion, $60 \%$ of the students stopped during the conversation to correct their mistakes while speaking in English, while the rest continued to speak irrespective of the mistakes being made. In terms of Arabic influence during the sentence framing, it was observed that $60 \%$ of the students were able to speak in English with negligible influence of Arabic. With respect to displaying confidence, only $40 \%$ of them reflected a positive attitude during the discussion to learn English language. Only 20\% of them complained about learning English due to a lack of support from teachers, lack of personal motivation (could attribute to family support) and poor teaching. This supports a number of academic researches which indicate the importance of hiring trained teachers who understand Arabic influence in learning English and the prominence of motivation.

\section{Discussion}

English has emerged as a universal lingua franca and counted as one of the most spoken languages. With English listed as an L2 in the majority of countries particularly in education and business, it has become imperative for students to learn the language (Drbseh, 2015; Engin and Seven, 2014; Alrabai, 2016). In this study, an examination of the cognitive, psychological, and personal factors and their extent of influence on the proficiency of Arab learners of English was reviewed.

As noted by a number of researchers (Bekdas, 2015; Dmour, 2015; Salameh, 2015), the successful acquisition of English language is driven by internal and external factors. Internal factors pertain to the attitude and motivation of the learner, while the external factors relate to the learning atmosphere and support. As stressed by Gupta (2008), it is important for learners to understand the application of English in real-time and in order to do so, they should strive to achieve fluency. In this research, it was observed that students - who come from different educational background as per their nationalities or the educational levels of their parents - perceived the acquisition of English language differently, with a majority linking it to future growth and minority stating it as a temporary requirement. Attitude of the learners to learn English plays a crucial role and is linked to their personal motivation. The high motivation to learn English in the subjects can be also linked with the aim to secure the future. As stated by Hanani (2009), proficiency in English is perceived as major criteria for working successfully in the Arab countries in high posts and in the Gulf region in particular. 
Among the factors, one factor that was found to impact heavily on student motivation was family support. The role of parents and family members extends beyond securing quality education. In the case of this research context, it extends to supporting and motivating the learners (while at home) to acknowledge and apply the knowledge in practice. A number of studies have highlighted that students who are motivated at the right level are able to improve their language and perform better in English on all fronts (Drbseh, 2015; Hanani, 2009; Qashoa, 2006). Furthermore, the impact of local culture should not affect or interfere with the acquisition of the new language (as proposed by Chomsky, 1965 and Krashen, 1981). Parents who fail to understand the importance of learning English for the next generation limit the learning capabilities of the children to a certain degree. Similarly, teachers who fail to build a positive learning environment with high influence of local language eventually may not achieve the expected outcome in terms of learning proficiency of English (Ansari, 2012).

\section{Conclusion}

The research aimed to examine the effect of psychological, cognitive, and personal factors and their extent of influence on the proficiency of Arab learners of English in the Gulf region. The factors were classified primarily as attitude, motivation and culture. Post review of the data gathered and discussed in this research concluded that the factors affecting the fluency of English of Arab learners in the Gulf region is influenced by psychological motivation, physical needs to apply it, and personal reasoning. It is recommended that the teaching strategy applied by English language teachers for Arabic students be reviewed and assessed in light of these factors. The focus should be on development of an integrative environment (both at the school and home) that supports student development through positive motivation, support in learning and most importantly, building the student attitude towards applying English language in everyday life.

\section{References}

Al Ghazali, F. (2006). First Language Acquisition Vs Second Language Learning: What Is the Difference? Birmingham: The University of Birmingham.

Alhaisoni, E. (2012). The Effect of Writing Proficiency on Writing Planning Strategy Use: A Case Study of Saudi Learners of English. International Journal of Linguistics, 4(3)

Alrabai, F. (2016). Factors Underlying Low Achievement of Saudi EFL Learners. International Journal of English Linguistics , 6 (3), 21-37.

Ansari, A. A. (2012). Teaching of English to Arab Students: Problems and Remedies. Educational Research, $519-524$.

Behbahani, A. R. (2016). A Survey of University Students' Knowledge of Vocabulary Learning Strategies and Influential Factors in Middle East. Journal of Language Teaching and Research, 7 (4), 646-654.

Bekdas, B. (2015). Indentifying Factors Related to Students' English Proficiency Levels through a Segmentation Method. Ankara: Ihsan Dogramaci Bilkent University.

Brown, D. J. (2014). Mixed Methods Research for TESOL. Edinburugh: Edinburugh Textbooks in TESOL.

Charise, A. (2007). More English, Less Islam? An Overview of English Language Functions in the Arabian/Persian Gulf. Retrieved January 29, 2017, from University of Toronto:

http://homes.chass.utoronto.ca/ cpercy/courses/eng6365-charise.htm

Chomsky, N. (1965) Aspects of the Theory of Syntax. Cambridge: MIT Press.

Clark, E. 1993. The Lexicon in Acquisition. Cambridge: Cambridge University Press.

Connerley, M. L., \& Wu, J. (2015). Handbook on Well-Being of Working Women. New York: Springer.

Creswell, J. (2013). Research design: Qualitative, quantitative, and mixed methods approaches. New York: Sage.

Derderian-Aghajanian, A., \& Cong, W. C. (2012). How Culture Affects on English Language Learners' (ELL's) Outcomes, with Chinese and Middle Eastern Immigrant Students. International Journal of Business and Social Science , 3 (5), 172-180. 
Dmour, A. (2015). The Effect of Using Arabic Language for Teaching English as a Foreign Language at Elementary Stage Schools in Jordan. Journal of Education and Practice , 93-97.

Drbseh, M. M. (2015). Motivation and attitudes towards learning English as a foreign language: a study of the Middle East Arab University students at Leeds University in UK. International Journal of Scientific and Research Publications, 236-257.

Engin, A. O., \& Seven, M. A. (2014). Factors Which Affect the Success in English Teaching in Turkey. (The Example of Erzurm). Erzurum: Atatürk University.

Eshghinejad, S., \& Gritter, K. (2016). EFL students' attitudes toward learning English language: The case study of Kashan University students. Cogent Education .

Gawi, E. M. (2012). The Effects of Age Factor on Learning English: A Case Study of Learning English in Saudi Schools, Saudi Arabia. English Language Teaching , 5 (1), 127-139.

Gupta, S. (2008). Communication Skills and Functional Grammar. Boston: Firewall Media.

Hamdallah, R. (1999). To Use or Not To Use Arabic in English Language Teaching. An-Najah University Journal for Research , 285-296.

Hanani, F. (2009). A Thesis in Teaching English to Speakers of Other Languages. Sharjah: AUS .

Hopkyns, S. (2014). The effects of global English on culture and identity in the UAE: A double-edged sword. Learning and Teaching in Higher Education: Gulf Perspectives, 11 (2), 1-20.

Kelle, U. (2006). Combining qualitative and quantitative methods in research practice: purposes and advantages. Qualitative Research in Psychology , 293-311.

Krashen, S. D. (1981). Second language acquisition and second language learning. New York: Pergamon.

Latu, M. F. (1994). Factors affecting the learning of English as a second language macroskills among Tongan secondary students. Joondalup: Edith Cowan University.

Nguyen, H. T., Warren, W., \& Fehring, H. (2014). Factors Affecting English Language Teaching and Learning in Higher Education. English Language Teaching , 7(8), 94-105.

Othman, F. H., \& Shuqair, K. M. (2013). The Impact of Motivation on English Language Learning in the Gulf States. International Journal of Higher Education , 2(4), 123-130.

Qashoa, S. H. (2006). Motivation among Learners of English in the Secondary Schools in the Eastern Coast of the UAE. Dubai: British University in Dubai.

Rabab'ah, G. (2014). Communication Problems Facing Arab Learners of English. Journal of Language and Learning , 180-197.

Rubin, A., \& Babbie, E. R. (2009). Essential Research Methods for Social Work. Belmont: Cengage Learning.

Saffarini, R., \& Ismail, M. (2008, March 1). Globalisation of the English language. Gulf News

Salameh, W. (2012). The Impact of Social and Economic Factors on Students' English Language Performance in EFL Classrooms in Dubai Public Secondary Schools. Dubai: The British University.

Watzlawik, M., \& Born, A) .2007 .(Capturing Identity: Quantitative and Qualitative Methods. New York: University Press of America.

Zainol Abidin, M., Pour-Mohammadi, M. and Alzwari, H. (2012). EFL Students' Attitudes towards Learning English Language: The Case of Libyan Secondary School Students. Asian Social Science, 8(2). 


\section{Appendix A: (Survey Questions)}

Section 1: Demographics

1. Age: years

2. Gender: Male $1 \quad$ Female 2

3. Nationality:

4. Parent's Education Level:
Mother: PhD Master
Father: $\mathrm{PhD}$ Master
Bachelor
High School
Uneducated
Do not know
Bachelor
High School
Uneducated
Do not know

\section{Section 2: General Background}

5. Do you feel equally comfortable using English and Arabic? Yes - No

6. At what age did you start to learn English?

7. Do you have English Language course in your study now?

8. At home, do you speak in Arabic or English with your Family? Arabic - English

9. Have you taken TOEFL or IELTS exams: Yes - No

If yes, which one: TOEFL - IELTS

10. Please circle your level of comfort in the following areas related to English:
5 = excellent $\quad 4=$ good
$3=$ fair
$2=$ weak
$1=$ not at all

Listening (

) Speaking (

) Reading (

) Writing ( )

11. On a 5 point rating scale, please answer the following:

5 = Strongly agree $\quad 4=$ Agree $\quad 3=$ Neutral $2=$ Disagree $\quad 1=$ Strongly Disagree

\begin{tabular}{|l|l|}
\hline $\begin{array}{l}\text { Studying English is important for me because it allows me to meet and converse with a variety of } \\
\text { people }\end{array}$ & 12345 \\
\hline $\begin{array}{l}\text { Studying English is important for me because I will be a more respected person who knows a foreign } \\
\text { language }\end{array}$ & 12345 \\
\hline Studying English is important for me because it makes me a more knowledgeable person & 12345 \\
\hline I feel that other students in class speak English better than I do & 12345 \\
\hline I get nervous and confused when I speak in English & 12345 \\
\hline I am studying English only because it is a requirement & 12345 \\
\hline If I had the opportunity to speak English outside the classroom, I would do it & 12345 \\
\hline Students of intellectual abilities can successfully learn and speak English fluently without lesson & 12345 \\
\hline If I want to speak English fluently, my teacher should encourage me to speak more often & 12345 \\
\hline I find that my English can improve if I am able to study more & 12345 \\
\hline My teacher motivates me to improve my English & 12345 \\
\hline My family supports me constantly in improving my English & 12345 \\
\hline Teachers ignore the speaking activities & 12345 \\
\hline My teacher allows me to speak in Arabic in the English Class & 12345 \\
\hline
\end{tabular}




\section{Appendix B: (Focus Group Questions)}

\section{Conduct a focus group with at least 5 students.}

A. Ask them to speak about their day in class for 3 minutes (individually) in English. Observe the following:

1. Is the student confident in expressing his/her views? Yes No

2. Is the student able to display diversity in vocabulary? Yes No

3. Does the student stop to correct a wrong sentence while speaking or carries on? Yes No

4. Does the student display an Arabic Influence in terms of creating dialects when speaking? Yes

B. Ask them to describe the importance of English and why they feel so. Observe the following:

1. Does the student have a positive attitude towards learning English?

2. Does the student complain about learning English? If yes, is it:

\section{Personal lack of motivation}

Poor teaching / teachers

Boring classes

Lack of support

Others

3. Does the student find English useful in future?

Yes No 